\title{
建筑工程现场施工技术管理攻略
}

李官文

江西华远项目管理有限公司

DOI:10.32629/btr.v2i10.2534

[摘 要] 近年来, 我国建筑工程规模与数量都在不断增加, 而在施工过程中现场施工技术管理仍存在许多不足之处,制约着建 筑工程施工质量的提升。为了能够得到人们的好评以及对建筑质量的肯定, 完善建筑工程现场施工技术管理就成为了当务之 急。基于此,文章分析了房屋建筑工程现场施工技术管理的意义和原则, 探析了房屋建筑工程实施现场施工技术管理的有效措 施, 旨在为房屋建筑工程的管理人员和技术人员提供一定的参考。

[关键词] 房屋建筑工程; 现场施工; 技术管理

在科学管理方式下提升建筑工程现场施工技术管理水 平, 对建筑工程现场涉及到的因素进行全面的分析, 组织协 调各部门之间的关系, 使建筑工程现场施工技术管理能够在 完善的规章制度下进行。施工技术管理要同生产要求相适应, 提升建筑工程管理的优质化发展。建筑工程现场施工技术管 理水平的提升能够为社会主义现代化建设提供更加完善的 服务。

\section{1 建筑工程现场施工技术管理的概述}

建筑工程现场施工技术管理指的是对施工方法、设计、 技术、工序的方方面面进行管理, 主要包括审核相关的技术 文件、编制可行的施工组织计划、进行技术交底和技术变更 等, 同时也包括施工进度、安全、质量和经济的管理。通过 科学地组织各项技术工作, 建立良好的技术秩序, 保证整个 工程施工符合国家技术规范的要求, 以达到高质量的完成工 程任务的目的。

\section{2 建筑工程施工技术管理的主要内容}

2.1 应县建立健全完善的建筑工程施工技术管理组织体 系, 以便确保施工现场施工技术管理工作的顺利开展。且管 理体系的人员因素应包含全面, 建筑工程技术管理人员、工 程师、施工人员等这些均应包含在内。

2.2 在建筑工程施工技术管理实践中, 应进行事前规范 控制和事后总结管理, 充分熟悉相关技术管理标准与施工操 作规程, 对现场施工及作业活动进行科学的指导, 让施工人 员充分了解并掌握作业程序和施工方式及相关工种技术要 领, 保证施工生产的安全和有序, 及时维护检修施工设备, 降 低因施工设备问题而增加的成本。

2. 3对投入使用的施工技术, 生产材料的特点、构配件状 况, 工程中使用的各种用品, 必须进行科学的记录和总结, 并 注重施工质量的检测和记录, 确保实时记录图纸的会审与设 计交底及各项设计变更情况, 并对工程质量控制与安全事故 分析处理资料进行妥善的归档整理, 从而保证工程建设进程 中的各项数据的真实性得到合理反应。

\section{3 施工现场管理的基本原则}

3. 1 经济效益原则。在总的工程量不变的情况下, 如果成
本投入量越大, 其效益就会降低, 反之则成本的投入量越少, 效益就会越大。所以在建筑施工现场中, 必须做好建筑材料 的合理有效的管理, 最大化的降低材料的浪费, 节约建筑材 料的成本, 从而使经济利益达到最大化。

3. 2 科学合理化原则。科学合理化原则是建筑施工现场 必须遵循的原则之一, 只有保证了施工现场管理的科学性和 合理性, 才能确保在施工现场管理中的经济效益原则, 为经 济利益提供了保障。施工现场管理的科学性与合理性能确保 工程施工顺利进行, 保证了工程质量。

3. 3 标准规范化原则。建筑工程施工现场管理应该严格 按照施工计划以及施工方案进行施工, 施工现场的标准化、 规范化能够使施工进度不会因为施工人员的技术问题而被 拖延, 有效提高施工效率, 保证了施工质量, 降低不规范施工 概率的发生。

\section{4 建筑工程现场施工技术管理的重要性}

4. 1 现场施工技术管理有助于提升建筑企业的市场竞争 力。现场施工技术管理是促进生产力规范发展的重要途径, 在对建筑工程进行现场施工技术管理时, 要对各项施工技术 进行优化组合, 并选择合理的、与施工条件相适应的技术, 促进施工生产效率的提升, 使建筑工程的质量能够得以保证, 经济效益得以提高。因此, 当建筑企业生产效率与生产质量 都得以提升时, 其核心的市场竞争力也会相应的得以提升。

4.2 建筑工程现场施工技术管理有助于提升建筑企业的 经济效益。在进行现场施工技术管理时, 需要对各种建设过 程中的有效资源进行合理配置; 在进行技术方案选择时, 需 要选择生产效率高、经济效益好的设计方案。所以, 通过这 些施工技术性的有效选择, 能够减少施工成本, 提高施工效 率, 优化施工方案。

4. 3现场建筑施工技术管理有利于严控建筑工程的质 量。现场施工技术管理的目的是为了保证施工进程的质量能 够有效保证。所以, 在进行施工技术监管时, 就需要对施工技 术是否达标、施工手法是否正确、施工中的技术选择是否合 理进行管理, 并在进行技术确认的同时融入科学的管理理念, 从而使得在进行建筑施工的同时, 能够严格控制建设工程的 
质量, 保证建筑的各项功都能够符合建设的规范标准。

\section{5 加强建筑工程现场施工技术管理措施}

5.1 建立建筑工程现场施工技术管理的基本制度。（1） 建立完善技术图纸的学习会审制度, 这一制度要求施工技术 人员要通过对施工技术图纸和施工现场的实际情况的认真 对比, 充分了解把握技术图纸的内容、要求、特点, 有效解决 技术图纸和实际施工的矛盾, 从而使现场施工高效、顺利、 安全、高质量的完成。(2) 建立完善施工企业参与制定技术 方案的制度。施工单位作为工程的具体执行建设单位, 应该 与建设单位、设计单位,一同设计和制定施工技术方案。从 而使施工单位有足够的准备时间, 明确技术方案的设计意图, 修正施工技术方案使其符合自身的技术管理条件, 及时正确 的反馈工程施工的信息, 提高施工技术方案的设计质量。(3) 建立完善材料的检验制度。配备专业的检验设备和检验人员， 明确检测方法、程序、具体要求等, 对施工材料和设备进行 技术检测, 确保施工材料和设备的质量, 从而提高建筑工程 的质量。(4) 建立完善档案资料管理制度。技术档案资料包 含着建筑单位积累的技术标准和科技成果, 是建设、施工、 设计单位进行技术管理、科学研究和生产的重要参考资料。 通过制度的确立, 把这些资料汇集整合起来, 能反映施工技 术管理的真实情况, 有利于工程后期的维护、改造和扩建, 这项制度的制定和实施，应该作为重要技术基础工作推进。

(5) 做好建筑工程现场施工设备管理和能源管理。建筑工程 建设中存在大量的密集劳动, 且人员素质较低, 造成生产效 率低下。随着时代的发展和技术的进步, 各类半自动、全自 动机械设备应用到建筑工程的现场施工中, 生产效率得到很 大提高。但不少建筑单位建造成本仍然居高不下, 主要原因 是浪费现象较重, 其中机械设备的选用、维护不当和能源浪 费现象比较突出。能耗较高的机械设备应当避免选择使用, 要注意机械设备的经济性选择, 避免违章使用和超负荷使用, 注重维护保养, 延长机械设备的使用期限。能源管理主要表 现在水、电、材料的使用上, 现场施工技术管理应该制定相 应的管理措施以消除浪费, 降低总体成本。(6) 加强建筑工程 施工现场材料管理。材料成本占建筑工程造价的最大比例, 所以施工单位应运用领先规划做好施工材料的成本预算和 管理, 有利于提高工程项目的效益。首先, 原材料的进货渠
道、性价比必须透明, 在确保材料质量的前提下优先选择报 价较低的供货商, 有利于减少材料费用的支出, 从而降低施 工成本。其次, 材料清单要科学、合理, 要以实际工程需要为 前提编制施工组织计划, 能够满足施工过程中材料、机械设 备总量的需求。此外, 施工方案应结合施工能力、建设要求 和标准进行, 并落实到各个施工组织, 除非出现技术无法解 决的问题, 否则不能随意变更施工计划, 不然会造成工程进 度、质量和资金方面的损失。最后, 节约意识应渗透到施工 各个阶段, 比如板材或其它可二次再利用的资源可回收再利 用, 发现浪费表象要制止, 由管理人员以身作则, 以此带动施 工现场节约、文明施工的风气。(7) 组建一支综合素质高的 施工管理团队人力资源是房屋建筑工程建设的第一要素, 同 时也是房屋建筑工程施工的管理者、组织者以及实施者。因 此, 应该提高现场施工技术人员的综合素质, 创建一支高素 质的管理团队。具体措施主要包括以下几个方面:

(1)根据房屋建筑工程的实际状况, 科学的编制施工技术 管理人员配置方案。(2)划分具体的工作岗位, 并具体化和明确 化责任。(3)加强对施工技术人员的培训, 提高房屋建筑工程现 场施工人员的职业素质与专业水平, 同时了解新材料、新技 术、新工艺的使用。通过创建一支高素质的施工管理团队, 对 于提高现场施工技术管理效率具有非常重要的作用。

\section{6 结语}

建筑工程现场施工技术管理内容较为复杂, 因此施工管 理人员要重视建筑工程现场施工技术管理水平的提升。并且 不断深化技术创新, 完善管理方式。这样才能够保证建筑工 程现场施工技术管理科学化发展, 更好的适应市场的需求与 行业的发展。

\section{[参考文献]}

[1]区嘉健.施工现场管理存在的问题及其优化策略探 析[J].知识经济,2013(12):88.

[2]武华.建筑施工现场项目管理分析 [J].建材与装 饰,2019(25):184-185.

[3]陈詹成.浅谈建筑工程现场施工技术管理问题及对策 [J].门窗,2015(05):284。

[4]王文生.建筑工程现场施工技术管理措施关键分析 [J].建材与装饰,2019(23):221-222. 